\section{Extrasensory deceptions}

\author{
Steve Blinkhorn
}

Parapsychology: A Concise History. By John Beloff. Athlone: 1993. Pp. 330.£32 (hbk); $£ 12.95$ (pbk).

SOME things never change. Sixty years ago, Harry Price published Leaves from a Psychist's Case Book, a compendium of some of his more interesting forays into purported paranormal phenomena. It is characterized by the excessive use of italics for emphasis and exclamation marks for assertion when the evidence is thin or the author feels his argument is less than convincing. It also contains some extraordinary photographs, which nowadays have the kind of period feel one sometimes associates with antique surgical apparatus. I am rather attached to my copy, which I inherited from my grandmother-in-law, partly because she squandered her modest fortune on supporting Harry Price's activities.

Sixty years on, Beloff's history of parapsychology has its full quota of italics and exclamation marks, lacking only the photographs. This is a shame, because its author seems to believe that thoughtography - the creation of photographic images on film by thought alone - is a genuine phenomenon. You can put photographs in a book, whereas ectoplasm eludes the publishing process. Photographs of ectoplasm might be a good sub-

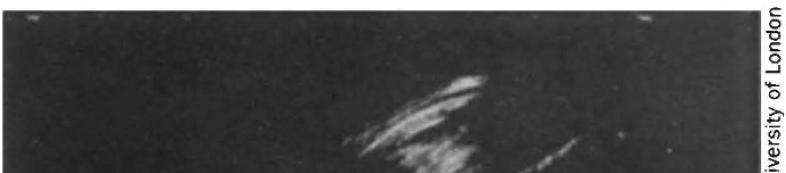
cheesecloth and butter muslin as a consequence of modern methods for the bulk processing of dairy products.

In fact, strong paranormal phenomena of all kinds have declined almost to vanishing point, just as good scientific methods for studying them have reached perfection - infrared cameras for the materialization of spirits in seances, for instance. Why should this be? I have three solutions to offer. First, a lot more people have died since the $1930 \mathrm{~s}$, and the consequent congestion in communication channels between this life and the 'other side' prevents effective and reliable contact. This we might call the cellular telephone

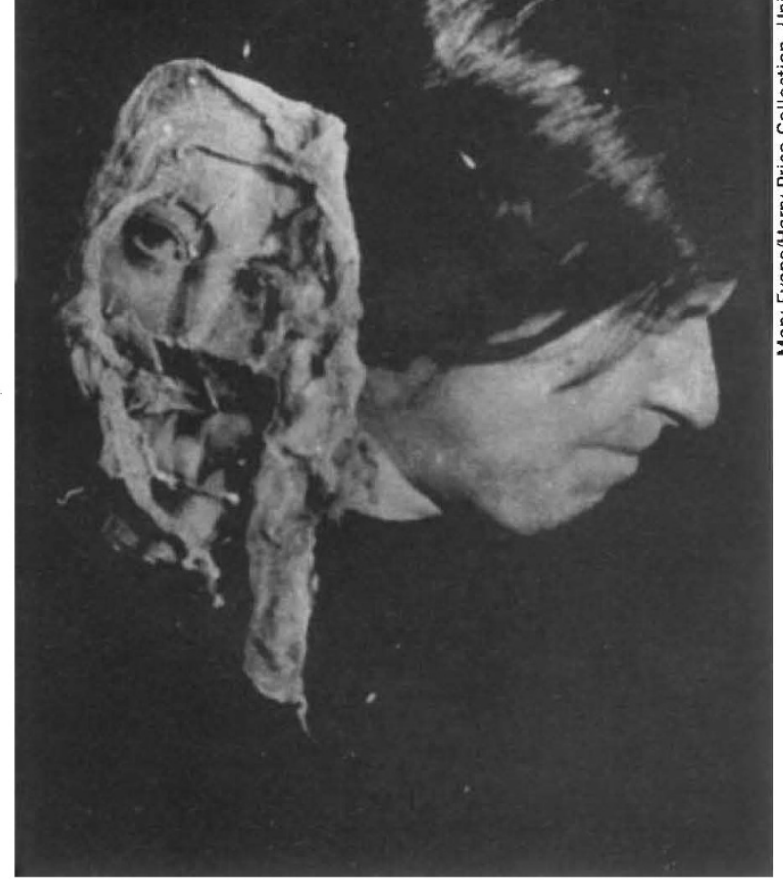

Two heads are better than one - "Like all photographs of ectoplasm, these curious structures may look spurious..." The medium Marthe Berauld tested by Schrenke-Nötzing, from a photograph in the Harry Price Collection.

stitute, for as Beloff puts it, with regard to ectoplasmic rods supposedly responsible for the levitation of a table: "Like all photographs of ectoplasm, these curious structures may look spurious ...."But we have to take his word for it, as all he gives us is text.

Ectoplasm, which when photographed tends to bear a striking resemblance to cheesecloth or butter muslin, generally has a marked preference for issuing from the upper rather than the lower end of the gastrointestinal tract (although in the case of the medium concerned in this particular case it came "mainly from her vagina"). Ectoplasmic manifestations have declined markedly in recent decades. I attribute this to the decline in the availability of hypothesis. Second, we have the politically correct hypothesis: Red Indian spirit guides have withdrawn their labour until the history of their participation in psychical research is rewritten, and we start calling them Native Americans as is their due. You can probably guess the third.

There has even been a shortage in recent years of spoon-bending phenomena, which attracted so much enthusiasm in the 1970s. Could it be that the widespread availability of video recorders destroys the conditions of calm and concentration upon which they depend?

"The community of sceptics is always ready to scoff", would sum up Beloff's response to such suggestions. But Sir
Oliver Lodge was quite keen on the idea that thought transference could be seen as an electromagnetic phenomenon transmitted through his beloved ether, and I fail to see why paranormal phenomena should not suffer the same restrictions as my mobile telephone. Anyway, as a hypothesis it is no more daft than his own suggestion, that nature acts as an extraordinary sort of immune system, fighting off paranormal manifestations, presumably with antispirits rather than antibodies.

Beloff repeatedly endorses the argument that where no conventional explanation of supposed paranormal phenomena has been forthcoming this is because no conventional explanation is possible. This is the common fallacy of paranormal claims. Similarly, in quoting the odds against particular results arising by chance, he takes the improbability of chance as suggestive of the probability that something paranormal has occurred. This style of argument will be depressingly familiar to many journal editors, not to mention those charged with instilling the rudiments of hypothesis testing in unwilling undergraduates.

Now there is one curious feature of nearly all of the cases he discusses: sooner or later the medium is discovered cheating, or poor experimental control is demonstrated. Psychic phenomena decline when investigators start to work out how they might be achieved by normal means. If we are to take Beloff seriously then providence prefers potential cheats when determining how to distribute psychic powers, as he is prepared to believe in the reality of the phenomena produced on those occasions when the actual method of cheating was not exposed.

This is a concise history, made all the more concise by the omission or minimization of cases that once made headlines, but subsequently proved insubstantial. For instance, who can forget Carl Sargent's experimental work at Cambridge in the 1970 s? Here he merits merely a mention in the notes and bibliography. We are left with the flotsam and jetsam of not quite totally discredited phenomena to interest true believers, a lot of frank description of fraud, some interesting potted early history, and a distillation of post-Renaissance philosophy of mind and miracles, which suffers greatly from a failure to consider mediaeval scholastic views on the nature of the soul and the ordering of nature.

Perhaps in sixty years' time this book will seem as quaintly outdated as Price's Leaves. Or perhaps it won't take nearly as long as that.

Steve Blinkhorn is at Psychometric Research and Develupment Ltd, Brewmaster House, The Maltings, St Albans, Herts AL1 3HT, UK. 